\title{
How to Identify Cognates in Syntax? Taking Watkins' Legacy One Step Further
}

\author{
Jóhanna Barðdal and Thórhallur Eythórsson
}

\begin{abstract}
As a reaction to three different proposals on how to reconstruct basic word order for Proto-Indo-European, Watkins and his contemporaries in the 1970 succeeded in aborting any attempt at reconstructing syntax for a long time to come. As a consequence, syntactic reconstruction has generally been abandoned, regarded as a doomed enterprise by historical linguists for several different reasons, one of which is the alleged difficulty in identifying cognates in syntax. Later, Watkins (1995) proposed a research program aimed at reconstructing larger units of grammar, including syntactic structures, by means of identifying morphological flags that are parts of larger syntactic entities. As a response to this, we show how cognate argument structure constructions may be identified, through a) cognate lexical verbs, b) cognate case frames, c) cognate predicate structure and d) cognate case morphology. We then propose to advance Watkins' program, by identifying cognate argument structure constructions with the aid of non-cognate, but synonymous, lexical predicates. As a consequence, it will not only be possible to identify cognate argument structure constructions across a deeper time span, it will also be possible to carry out semantic reconstruction on the basis of lexical-semantic verb classes.
\end{abstract}

\section{Introduction}

While phonological, morphological and lexical reconstruction continue to thrive in historical-comparative linguistics, syntactic reconstruction has been balked at for several decades now, ever since the influential article by Watkins (1976) in which three different reconstructions of basic word order in Proto-Indo-European were weighed, measured and found wanting.* Since

* We are indebted to the audiences in Ghent (2014), Brussels (2014), and Vienna (2014) for discussions; to Valgerður Bjarnadóttir, Eleonora Cattafi, Serena Danesi, Tonya Kim Dewey, Michael Frotscher, Leonid Kulikov, Roland Pooth and Valentina Tsepeleva for discussions and

(C) JÓHANNA BARĐDAL AND THÓRHALLUR EYTHÓRSSON, 2020 | DOI:10.1163/9789004392007_006 
then, different forces have made an entrance into the field of syntactic reconstruction, most notably Harris and Campbell who systematically argued for the feasibility of syntactic reconstruction (Harris \& Campbell 1995, Campbell \& Harris 2003), but were remonstrated against by Lightfoot and his followers (Lightfoot 2002a, 2002b; Pires \& Thomason 2008). The debate on the legitimacy of syntactic reconstruction continues, although it seems that there is more resonance in the historical linguistic community with syntactic reconstruction now than ever before (cf. Gildea 1998, 200o; Mendoza 1998; Bauer 2000; Kikusawa 2002, 2003; Roberts 2007; Bowern 2008; Willis 2011; Kulikov \& Lavidas 2013; Walkden 2014; Viti 2014; Smitherman 2015; Daniels 2015, 2017; Dunn et al. 2017; Danesi, Johnson \& Barðdal 2017; Pooth et al. 2019; Johnson et al. 2019; inter alia), despite there still being strong forces in the community arguing against it (Pires \& Thomason 2008; Mengden 2008; Walkden 2013; Seržant 2015).

Our goal in this article is to take Watkins' legacy, that syntax is reconstructable on the basis of morphological clues, one step further. A central question to be dealt with is how to identify cognates in syntax. We propose that within the area of argument structure constructions, cognate argument structures may be identified as such on the basis of a) cognate lexical material, b) cognate case frames, c) cognate predicate structure and d) cognate case morphology. After demonstrating in practice the viability of the proposed research program, we proceed to show how cognate argument structure constructions may be identified on the basis of non-cognate, but synonymous, lexical material. This last step in the methodology entails improving on Watkins' proposal, such that cognate argument structure constructions are not only identifiable on the basis of morphological or morphosyntactic clues, but also on the basis of semantic clues.

In Section 2 we give an outline of the problem, which has its roots in the marginal status of syntax during the Neogrammarian period, the underdeveloped syntactic theories of the structuralists, as well as a putative fundamental difference between phonology, morphology and the lexicon, on the one hand, and syntax on the other. We briefly discuss four of the five major arguments that have been presented against syntactic reconstruction, before turning to the fifth, the alleged lack of cognates in syntax, in Section 3. There we showcase how cognates in argument structure may be identified, illustrating our point

help with the data. Thanks also go to two anonymous reviewers as well as Spike Gildea and Eugenio Luján. This research was supported with two generous research grants to Jóhanna Barðdal, the first from the Norwegian Research Council (NonCanCase, grant nr. 205007) and the second from the European Research Council (EVALISA, grant nr. 313461). 
with a reconstruction of the argument structure constructions of three verbs, 'think', 'thirst' and 'answer', for Proto-Germanic. What these three verbs have in common is that they all deviate from the canonical Nom-Acc transitive prototype, hence exhibiting a certain degree of arbitrariness in the linking between case marking and grammatical relations.

Moreover, we present a general argument against the arbitrariness requirement in syntax, and claim instead that canonical structures are reconstructable as such on the basis of common regularities in the daughter languages, exactly as for phonology, morphology and the lexicon. Our reconstructions are in part based on attested syntactic changes, that are regular in nature, indeed demonstrating the directionality that has been presumed to be absent in syntax.

It has been consistently assumed in historical linguistics that syntactic reconstruction is more or less untenable (Watkins 1976; Jeffers 1976; Winter 1984; Lightfoot 1979, 2002a, 200ob, 2006; Harrison 2003; Holland 2003; Pires \& Thomason 2008; von Mengden 2008). The reasons for this are five-fold:

- lack of regularity in syntactic change

- lack of arbitrariness in syntax

- lack of simple form-meaning correspondences in syntax

- lack of continuous transmission of syntactic structures during acquisition

- lack of cognate material in syntax

Let us start with the lack of regularity in syntactic change, since regularity has been a key concept for deciding on the potential directionality of syntactic change. This idea of lack of regularity is based on the notion that while sound change is regular and can be captured by sound laws, syntactic change, in contrast, is not; there are no syntactic "laws" that can be used in reconstruction to determine the regularity of change (cf. Miranda 1976; Lightfoot 1979, 2002a; Campbell \& Mithun 1980), aiding in the decision of which alternant of a correspondence set provides basis for the reconstruction.

This first criticism of syntactic reconstruction is based on two misconceptions. The first misconception is that the sound laws are regular and apply without exception. The second one is that there is no regularity, and hence no directionality, in syntactic change. The truth of the matter is first that sound laws are only regular by definition (Hoenigswald 1978), while semi-regular and less regular sound changes are as such systematically excluded from the notion of a sound law. Thus, not all phonological changes can be reconstructed on the basis of sound laws. Second, contrary to widespread beliefs, regularity 
can indeed be found in syntactic change, although as Willis (2011) points out, this regularity is local and not necessarily universal. In other words, by carefully examining the data, regularities may be discerned, although this clearly has to be done on the basis of each data set and that data set alone (cf. also Harris \& Campbell 1985; Campbell \& Harris 2003; Barðdal \& Eythórsson 2012a; Dunn et al. 2017).

Turning to the second and the third criticisms listed above, the general conception within the historical linguistic community is that syntax lacks the form-meaning correspondences which are needed to provide a basis for a secure reconstruction, and hence that the arbitrariness requirement cannot be fulfilled in syntax.

Exactly as the first criticism, the second one is also based on two misconceptions: first, there is in fact a great deal of arbitrariness in syntax, contra the received opinion, and second, in any case, the requirement of arbitrariness is simply not needed in syntax. Harrison (2003) argues that the requirement of arbitrariness is first and foremost relevant when the goal of the reconstruction is to establish genetic relatedness. Since syntactic reconstruction is usually carried out after genetic relatedness has been established, the arbitrariness requirement is superfluous in syntax. In addition, as we discuss below, there is a substantial amount of arbitrariness in syntax, so the requirement can in part be fulfilled in any case.

The third criticism, that syntax does not consist of simple form-meaning correspondences, has its roots in the traditionalist/structuralist view of sentence meaning, namely that the meaning of a sentence is derived from the meaning of the lexical items instantiating it (cf. Klein 2010). On such a view, sentences do not consist of form-meaning correspondences, but are instead combinations of words and phrases, according to specific rules.

This third criticism does not apply on a constructional approach to language where larger syntactic units than words are regarded as form-meaning correspondences (Fillmore et al. 1988; Goldberg 1995; Croft 2001; inter alia). On a constructional approach, not only words are regarded as signs, in the Saussurian sense, but also larger constructions. In fact, constructions are assumed to range on a scale from lexically filled to schematic constructions, as well as ranging on a scale from the atomic to the bound, and from the bound to the combinatoric (cf. references in Croft \& Cruse 2004). On a constructional approach, therefore, syntactic entities also count as form-meaning correspondences, and are as such legitimate objects of the Comparative Method (Eythórsson \& Barðdal 2011, 2016; Barðdal \& Eythórsson 2012a, 2012b; Barðdal 2013, 2014; Daniels 2015; Danesi, Johnson \& Barðdal 2017; Johnson et al. 2019; Vázquez-González \& Barðdal 2019). 
The fourth criticism, concentrating on the issue of the alleged lack of continuous transmission of syntactic structures during acquisition, was in particular put forward and emphasized by Lightfoot (1979, inter alia). The idea here is that words are inherited from one generation to the other, while clauses are not, since the speaker does not inherit the grammar of his/her language, but derives it on the basis of the input.

This fourth criticism of syntactic reconstruction is based on quite a simplistic view of lexical items, as being somehow less abstract than clauses (Barðdal \& Eythórsson 2012a). In fact words are complex form-meaning correspondences and are as such abstract entities (cf. Adger 2003; Tomasello 2003; Goldberg 2006: 69ff). This means that there is, in essence, no qualitative difference between the transmission of lexical items and larger structural units. We realize that this goes against a widely held view, but it follows naturally from the explicit tenets of Construction Grammar, where larger units than lexical items are regarded as form-meaning correspondences exactly like words. As such, larger schematic units can be inherited from one generation to the next exactly like words (Eythórsson \& Barðdal 2011; Barðdal \& Eythórsson 2012a, 2012b).

We have dealt extensively with these first four arguments against syntactic reconstruction elsewhere; hence, in the following, we focus primarily on the last problem, namely that of how to identify cognates in syntax. Nevertheless, regularity in syntactic change, and arbitrariness, will also figure in the discussion and argumentation below.

It is generally assumed in the historical linguistic community that identifying cognates in syntax is a hopeless venture. As is well known, during the early 1970s, three historical linguists launched three different reconstructions of the basic word order of Proto-Indo-European. Lehmann (1974), following Delbrück (1878, inter alia), claimed that Proto-Indo-European was an sov language, Friedrich (1975) claimed that it was an svo language, and Miller (1975) that it could have been an svo, sov or vso language. Lehmann founded his claims on the typological work of Greenberg, and argued for his position on the basis of typological correlations between basic word order and the word order within the noun phrase, the prepositional phrase and the adjectival phrase. Friedrich's claim is grounded in a frequency count of different word orders in early texts, in particular Homer; by means of which he found that svo dominates over sov. Finally, Miller founded his claims on the later development of the word order in the Indo-European languages, where all three word orders are attested.

These three different approaches to one and the same phenomenon, basic word order in Indo-European, attracted much antagonistic attention from 
contemporary historical-comparative linguists at the time. In particular, Watkins (1976) put forward severe criticism of this whole enterprise which he regarded as a major fiasco. Although justified, Watkins' criticism, in effect, annihilated any further attempts at reconstructing syntax for decades. As a consequence, studies on syntactic reconstruction came to a halt and did not gain ground again for a long time to come.

In retrospect, seen from a modern perspective, the work of the troika from the early 1970s, Lehmann, Friedrich and Miller, may of course have been a fumble in the dark. However, given the fact that theoretical syntax was still an underdeveloped field at the time, and historical syntax even more so, any attempts at syntactic reconstruction were bound to be lightweight and imperfect. Thus, the failure of these early attempts reflects shortcomings of their models and not of the enterprise in and of itself.

Watkins himself did not suggest a systematic program for how to reconstruct syntax. Instead, he emphasized that syntactic reconstruction should be based on archaic expressions containing frozen syntax, deviations from productive patterns, and any anomalies in the language that cannot be explained synchronically. He also pointed out that in order to be able to carry out syntactic reconstruction, one has to examine the data carefully, compare linguistic units used to express similar content across the daughter languages, and in general compare cognate text traditions based on oral transmission of inherited cultural and linguistic material. In other words, Watkins did not directly address the cognacy problem.

In the same year Jeffers (1976) also problematized the issue of reconstructing syntax and claimed that there is no finite set of sentences which can be used as input for correspondence sets in syntax. He argued that one of the main problems with reconstructing syntax is that syntactic change takes place through pattern replacement, but does not necessarily involve small changes in inherited patterns, which is the kind of change needed to identify inherited patterns across daughter languages. In other words, Jeffers' claim means in essence that there can be no cognates in syntax in the same sense as in phonology, morphology and the lexicon. This position has been the prevailing view on syntactic reconstruction for decades. Below, we present examples from syntax which falsify this claim.

Watkins' main contribution to the debate on syntactic reconstruction, initiated in his early work and laid out in more detail in his 1995 book, How to Kill a Dragon, was that morphological clues are instrumental for identifying cognates, including cognate syntactic material (cf. also Watkins 1964; Fox 1995; Gildea 1998; Kikusawa 2003; Harris 2008). Watkins' own work on poetic formulae consistently identifies layers of cognate collocations and prefabs across 
the Indo-European traditions, showing how fragments of earlier syntax can be determined and, hence, reconstructed.

Taking Watkins' method at face value means that essentially all morphosyntax constitutes a potential input for correspondence sets, and therefore provides a basis for comparative reconstruction. This is by no means an insignificant proportion of grammar: all morphosyntax. In addition, following Watkins' method, collocations and prefabs may provide information about word order and clause structure of earlier stages, which in turn means that such abstract units can be detected and reconstructed (cf. Comrie 1980). Thus, despite the pessimistic tone of Watkins' (1976) article, there are more possibilities inherent in his approach than he and many of his epigones may have realized. Prospects for syntactic reconstruction are therefore not as gloomy as commonly assumed. In Barðdal et al. (2013) we showed how morphosyntactic reconstruction can be expanded into the domain of information structure, and below we will argue that it can be extended into the domain of semantics as well (cf. also Barðdal 2007, Barðdal et al. 2012; Johnson et al. 2019).

Finally, let us consider the question of why syntactic reconstruction is important at all. Syntactic reconstruction is not simply a hobby of some armchair linguists who enjoy playing with historical data; it is a fundamental part of historical linguistics, as it involves putting forward grounded hypotheses on prestages of languages, and hence aims at identifying how language change comes about (cf. Ferraresi \& Goldbach 2008). Syntactic reconstruction is thus a way of concretizing and "formalizing" analyses of language change. As such, syntactic reconstruction may provide important insights into the development of specific linguistic structures. We now turn to the issue of how to identify cognates in syntax.

\section{Identifying Cognates in Syntax}

We first discuss cognate recognition in syntax on the basis of cognate lexical material (Section 3.1), second, on the basis of cognate structure, including argument and predicate structure (Section 3.2), and finally, we show how Watkins' program can be taken one step further, namely through cognate recognition in syntax on the basis of synonymous lexical material (Section 3.3).

\subsection{Identification on the Basis of Cognate Lexical Material}

In order to extend Watkins' method to reconstruct on the basis of morphosyntax, let us now delve into the realm of argument structure, since a substantial part of our syntactic work has been focused on that domain of grammar. 
TABLE 5.1 Lexical correspondence sets for Germanic 'think'

\begin{tabular}{llll}
\hline & FORM & MEANING & RECONSTRUCTED FORM \\
\hline Gothic & pugkjan & 'think, seem' \\
Old High German & thunkian & 'think, seem' \\
Old English & pyncan & 'think, seem' \\
Old Saxon & thunkian & 'think, seem' \\
Old Norse-Icelandic & pykkja & 'think, seem' \\
& & & \\
\hline
\end{tabular}

Argument structure is understood here as the arguments selected by a predicate and their relative order. Included in this are different case frames inherent in different argument structure constructions, like Nom-Acc, Nom-Dat, Nom-Gen, etc. As valency is a major ingredient in syntax, the ability to reconstruct argument structure is, we believe, a very significant contribution to a research program aiming at syntactic reconstruction.

Let us start with an investigation of a predicate selecting for a non-canonical case frame as a part of its argument structure. For instance, the oldest verb meaning 'think, seem' in the Germanic languages has been reconstructed as * bunkjan by historical linguists (see, for example, Kluge 2002), on the basis of the forms and the meaning in the earliest daughters. Table 5.1 gives the lexical correspondence set, on the basis of which the reconstructed form has been posited. As is evident from the table, the forms are clearly related and the meaning is the same.

Consider now some examples of the argument structure of this verb in the earliest layers:

Gothic

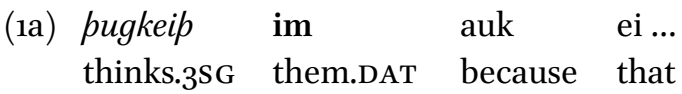
'for they think that ...' (Mt 6.7)

\section{Old High German}

(ib) samomichel uuunder mag temo dunchen, der... same.great wonder.NOM may.3SG him.DAT seem.INF who.NOM 'He will think it an equally great wonder, who ...' (Notker 1,283,9) 
Old English

(1c) Ne pynceð me gerysne pætwe rondas beren eft to earde not thinks.3SG me.DAT appropriate that we shields bear back to earth 'I do not find it appropriate that we bear our shields back home'

(Beowulf 2653)

Old Saxon

(1d) than thunkid imu, that he sie gerno forð lêstien uuillie then seems.3SG him.DAT that he it gladly forward do.INF wishes 'Then he thinks that he will gladly wish to do it in the future'

(Heliand 2496-2501)

Old Norse-Icelandic

(1e) oss pykir eigi verr að pú sért lítt heil us.DAT seems.3Sg not worse that you are little healthy 'we don't find it worse that you are not well' (Fóstbræðra saga, Ch. 10)

As these examples show, the first argument of the argument structure, the subject, is always in the dative case (for the subject behavior of non-nominative subjects in early Germanic, see Rögnvaldsson 1991, 1995; Allen 1995; Barðdal 2000; Barðdal \& Eythórsson 2003, 2012b; and Eythórsson \& Barðdal 2005). The morphological case markers in Germanic are also cognate; no innovative morphology is found in the case paradigm. It is certainly true that dative and instrumental have merged at some point in proto-history (Luraghi 1987; Barðdal \& Kulikov 2009), reflexes of which are documented in early West-Germanic (see, for example, Krahe 1969a). This, however, is not relevant here, as the dative with 'think' is hardly of instrumental origin. Table 5.2 gives an overview of the case marking of the subject of 'think' in both the early and the modern stages of the Germanic languages.

Observe that in the oldest languages 'think' consistently occurs with a dative subject. To be sure, accusative is also attested in Old High German, but apart from that it is only attested in the later stages. Nominative subjects with 'think' are first attested in Middle High German, and subsequently in Modern German, as well as in the Modern Germanic languages that have lost case marking. The data presented in Table 5.2 are in accordance with the wellknown tendency that oblique subjects change into nominative in the course of time (Jespersen 1927; Seefranz-Montag 1982; Eythórsson 2000, 2002; Barðdal 2009, 2011a). Notice also that Old Swedish, Middle High German, Middle English and Middle Dutch, which are more or less contemporaneous with Old Norse-Icelandic, have all innovated from the original case frame. In that sense they have gone further in their development than Icelandic. 
TABLE 5.2 Predicate-specific correspondence sets for the argument structure of Germanic 'think'

\begin{tabular}{|c|c|c|c|}
\hline & Alt 1 & Alt 2 & Alt 3 \\
\hline Gothic & DAT-'thinks' & & \\
\hline Old English & DAT-'thinks' & & \\
\hline Old Saxon & DAT-'thinks' & & \\
\hline Old High German & DAT-'thinks' & ACC-'thinks' & \\
\hline Old Norse-Icelandic & DAT-'thinks' & & \\
\hline Old Swedish & DAT-'thinks' & ACC-'thinks' & \\
\hline Middle English & DAT-'thinks' & ACC-'thinks' & \\
\hline Middle Dutch & & ACC-'thinks' & \\
\hline Middle High German & DAT-'thinks' & ACC-'thinks' & NOM-'think' \\
\hline Modern Icelandic & DAT-'thinks' & & \\
\hline Modern Faroese & DAT-'thinks' & & \\
\hline Modern Dutch & DAT-'thinks' & ACC-'thinks' & \\
\hline Modern High German & DAT-'thinks' & ACC-'thinks' & NOM-'think' \\
\hline Modern Swedish & & & NOM-'think' \\
\hline Modern English & & & NOM-'think' \\
\hline
\end{tabular}

We propose that the argument structure of 'think' can be reconstructed for Proto-Germanic, containing a dative subject, on two grounds:

- The earliest representatives of Germanic have a dative subject

- Accusative and nominative subjects are an innovation, attested first in the later layers, also in accordance with known developmental paths of oblique subjects

This proposal amounts to claiming not only that the predicate itself is cognate, but also its argument structure. We have identified the argument structure as a cognate argument structure, inherited from a common proto-stage, on the basis of three factors:

- The lexical predicate (including both its form and meaning) is cognate

- The case frame itself is cognate

- The morphological case markers are cognate

This is an example of how an argument structure construction can be identified as cognate in the preserved material. Let us now reconstruct this argument structure construction for Proto-Germanic. For that purpose we employ 




FIGURE 5.1 A reconstruction of the argument structure of 'think' in Proto-Germanic

the formalism of Construction Grammar (Kay \& Fillmore 1999; Michaelis \& Ruppenhofer 2001; Boas 2003; Fried \& Östman 2005; Michaelis 2009, 2012; Sag 2012; Fried 2015). Observe that the proposed reconstruction is only a partial reconstruction, based only on information about the subject argument.

The reconstruction, found in Figure 5.1, consists of three fields, a FORM field, a SYN field and a SEM field. The FORM field specifies the reconstructed form of the verb 'think' as *punkjan; the sYN field gives the case marking of the dative argument; the semantics of this verb-specific construction is given in terms of semantic frames (see Framenet ${ }^{1}$ ), in this case the Regard frame, where the subject is a COGNIZER, marked with an $i$, coindexed with the dative NP of the SYN field (for Frame Semantics, see Fillmore 1982, 1985; Petruck 1996; Fillmore \& Baker 20o9; inter alia). This is how verb-specific argument structure constructions may be reconstructed for earlier unattested proto-stages.

In addition to the reconstruction of verb-specific argument structure constructions as in Figure 5.1, it is also possible to reconstruct constructions at a higher, more schematic, level than the one proposed there. This may involve verb-subclass and verb-class-specific argument structure constructions that exist irrespective of the lexical items instantiating them. We refer the interested reader to Barðdal \& Smitherman (2013) and Vazquez Gonzalez \& Barðdal (2019) for a detailed exposition of the methodology and formalism. It follows from this that argument structure constructions, including their case frames, do not only exist at the substantive level, but also at different levels of schematicity.

Now it might be objected that dative subjects are ubiquitous with experiencer predicates cross-linguistically, and hence, dative subjects might be expected

1 The Framenet Project, available at framenet.icsi.berkeley.edu. 
to arise independently in languages because of common cognitive and conceptual constraints, and therefore are not necessarily inherited. However, one must also take into account the argument of economy, or Occam's razor, which, where it is possible, privileges inheritance (no changes) over innovation (one or more changes). And of course, if the typological ubiquity of dative experiencers could be invoked as a motivation for dative subjects in the modern languages, then it should be equally valid as a motivation for a dative subject in the proto case frame. As such, there are three major arguments for assuming an inheritance here, namely the three reasons stated in the bulleted list above: cognate lexical predicates, cognate case frames and cognate case markers. Moreover, dative subjects are also a clear deviation from the canonical argument structure with a nominative subject, found with the overwhelming majority of predicates, including experiencer predicates (cf. Jónsson 2003; Nichols 2008). Also, given the large pool of potential lexical predicates with experiencer meaning, exactly which ones get assigned non-canonical subject case marking and which do not appears idiosyncratic. As such, dative subjects definitely exhibit a certain degree of arbitrariness.

We continue with a discussion of the logical basis for the arbitrariness requirement for reconstruction in Section 3.2 below. But first, let us consider another predicate with a non-canonical subject case marking other than the dative, namely the verb 'thirst' which selects for an accusative subject in the early and archaic Germanic languages. This is important because accusative subjects are far less common in the world's languages than dative subjects (see, for instance, Barðdal 2009 on Old and Modern Icelandic), involving an even higher degree of arbitrariness than datives. The lexical correspondence set for 'thirst' is given in Table 5.3, on the basis of which a verb meaning 'thirst' has been reconstructed for Proto-Germanic (cf. Kroonen 2013: 553).

TABLE 5.3 Lexical correspondence sets for the Germanic verb 'thirst'

\begin{tabular}{llll}
\hline & FORM & MEANING & RECONSTRUCTED FORM \\
\hline Gothic & paursjan & 'thirst' & \\
Old High German & dursten & 'thirst' & \\
Old English & pyrstan & 'thirst' & *purs $(t)-$ \\
Old Saxon & thurstian & 'thirst' & \\
Old Norse-Icelandic & pyrsta & 'thirst' & \\
& & & \\
\hline
\end{tabular}


The examples below document the argument structure of 'thirst' in the earliest layers of Germanic:

\section{Gothic}

(2a) pana galaubjandan du mis ni paurseip hvanhun the.one.Acc believing in me not thirsts.3SG ever 'he that believes in me shall never thirst' (John, 6:35)

Old High German
(2b) thaz mih
ni thurste
so.that me.ACC not thirsts.3SG
'So that I do not thirst' (Tatian 87,5 )

Old English

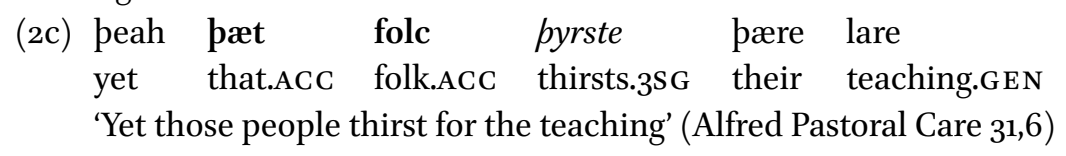

Old Saxon

(2d) quad that ina thurstidi
said that him.ACC thirsted.35G
'He said he was thirsty' (Heliand $5640 \mathrm{O}-5642 \mathrm{a}$ )

Old Norse-Icelandic

(2e) Pyrstir mig nú pví að eg em óvanari erfiðinu en pú. thirsts.3SG me.ACC now for at I am less.used.to hard.work than you 'I am thirsty now because I'm less used to hard work than you.'

(Porsteins Páttur Stangarhöggs)

As these examples show, the verb 'thirst' occurs systematically with an accusative subject in the earliest Germanic languages. There is some variation, however, at later stages, as shown in Table 5.4.

Observe that all the oldest languages display an accusative, which is preserved into later medieval stages, and surviving into modern times in Icelandic and German. The only language that shows variation in its earliest texts is Old English, with 'thirst' being documented with a dative and a nominative subject, in addition to the accusative. The dative survives into Middle English and is also documented in Middle Dutch. Except for in Old English, the nominative is 
TABLE 5.4 Predicate-specific correspondence sets for the argument structure of Germanic 'thirst'

\begin{tabular}{|c|c|c|c|}
\hline & Alt. 1 & Alt. 2 & Alt. 3 \\
\hline Gothic & ACC-'thirsts' & & \\
\hline Old High German & ACC-'thirsts' & & \\
\hline Old Saxon & ACC-'thirsts' & & \\
\hline Old English & ACC-'thirsts' & DAT-'thirsts' & NOM-'thirst' \\
\hline Old Norse-Icelandic & ACC-'thirsts' & & \\
\hline Middle High German & ACC-'thirsts' & & \\
\hline Middle English & ACC-'thirsts' & DAT-'thirsts' & \\
\hline Middle Dutch & ACC-'thirsts' & DAT-'thirsts' & \\
\hline Old Swedish & ACC-'thirsts' & & \\
\hline Modern Icelandic & ACC-'thirsts' & & \\
\hline Modern High German & ACC-'thirsts' & & NOM-'thirst' \\
\hline Modern Faroese & & & NOM-'thirst' \\
\hline Modern Swedish & & & NOM-'thirst' \\
\hline Modern English & & & NOM-'thirst' \\
\hline Modern Dutch & & & NOM-'thirst' \\
\hline
\end{tabular}

only documented in the modern stages of the Germanic languages. The reason that the nominative is documented already in the earliest stage of English with 'thirst' is most likely due to the early mergers of the morphological case markers in that language, as opposed to in the other Germanic languages where the case system did not collapse until later (Allen 1995; Falk 1997; Barðdal 2009).

To sum up, Table 5.4 outlines a development from accusative marking on the subject to nominative marking. This in turn suggests that it is in fact the accusative subject that is original with this verb. Again, we have identified cognate argument structure constructions with the verb 'thirst' in Germanic. Exactly as with 'think', this can be done on two grounds: a) the earliest representatives of Germanic have an accusative subject, and b) dative and nominative subjects are an innovation, attested first in the later layers, also in accordance with known developmental paths of oblique subjects. As with the verb 'think', there are three main arguments for assuming that the accusative subject construction is inherited from a common proto-stage: 


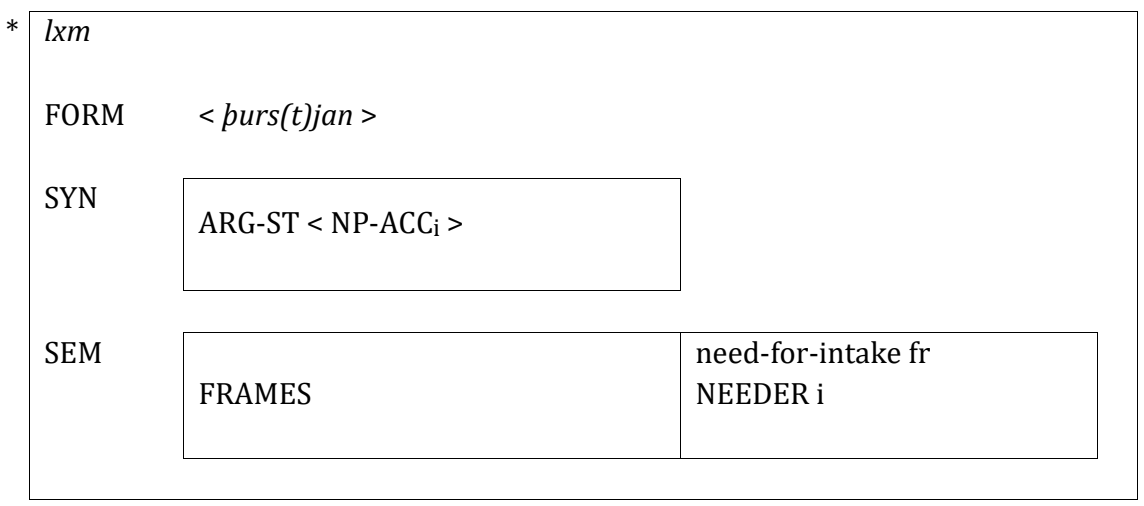

FIGURE 5.2 A reconstruction of the argument structure of 'thirst' in Proto-Germanic

- The lexical predicate (including both its form and meaning) is cognate

- The case frame itself is cognate

- The morphological case markers are cognate

On this basis, the argument structure construction of 'thirst' can be reconstructed, with the use of the Construction Grammar formalism, as in Figure 5.2, which has a parallel structure to that of 'think' in Figure 5.1.

The semantic frame we propose for 'thirst' is a subframe of Framenet's biological_urge frame, or more specifically the Need_for_intake_of_nourishment frame. This frame has already been suggested for 'hunger' (Barðdal \& Eythórsson 2012b), on the basis of an earlier analysis involving the frame for 'eat' (Croft 2oog).

As a final example in our proposed research program, let us consider 'answer' in Germanic which is lexically manifested by two different etymons, namely those reconstructed as * (and)swaran and *andwurdjan. Table 5.5 gives our correspondence sets and lexical reconstruction for *(and)swaran and Table 5.6 for *andwurdjan.

TABLE 5.5 Lexical correspondence set and reconstruction of Germanic * (and)swaran

\begin{tabular}{llll}
\hline & FORM & MEANING & RECONSTRUCTED FORM \\
\hline Old English & andswarian & 'answer' & \\
Old Frisian & andswara & 'answer' & \\
Old Norse-Icelandic & svara & 'answer' & *(and)swaran \\
Old Swedish & svara & 'answer' & \\
Old Danish & swarce & 'answer' & \\
& & & \\
\hline
\end{tabular}


TABLE 5.6 Lexical correspondence set and reconstruction of Germanic *andwurdjan

\begin{tabular}{llll}
\hline & FORM & MEANING & RECONSTRUCTED FORM \\
\hline Gothic & andwaurdjan & 'answer' & \\
Old High German & antwurten & 'answer' & \\
Old Frisian & andwerda & 'answer' & *andwurdjan \\
Old Saxon & andwurdian & 'answer' & \\
Old English & andwyrdan & 'answer' & \\
Middle Dutch & antwerden & 'answer' & \\
& & & \\
\hline
\end{tabular}

Table 5.5 suggests that the distribution of the etymon *(and)swaran is confined to North-Germanic and Ingvaeonic, while Table 5.6 shows that the etymon *andwurdjan is found in Gothic and West-Germanic. Note that there also exists a Gothic verb swaran with a different meaning, 'swear (an oath)' cf. Kroonen (2013: 496). In the other languages, this meaning is expressed with a verb containing a -ja suffix, namely *swarjan. Brugmann (1913) assumes a semantic development 'swear (an oath)' from 'answer before a court of justice'. This account presupposes that the meaning 'answer' is the original meaning, while 'swear (an oath)' is derived. This is further confirmed by the existence of related forms in other Indo-European languages, like Old Indic svara- 'sound', Oscan sverrunei 'spokesperson' and Old Church Slavonic svara 'quarrel' (de Vries 1962: 568).

Given the existence of the verb *swaran in all three branches of Germanic, it is reasonable to assume that it also existed in Proto-Germanic. But, it is also clear from the data that this verb had a competitor, namely *andwurdjan, with the same meaning as * (and)swaran 'answer'. This *andwurdjan consists of two components: a) the verb *wurdjan (Goth. waurdjan, OE wyrdan, ON-I orða, etc.) meaning 'speak, put into words', derived from the noun *wurdan 'word' (Goth. waurd, OE, OS, OFr. word, OHG wort, ON-I orð, etc.), and b) the prefix *and-. With the addition of this prefix, *andwurdjan came to mean 'speak against, oppose', and from there the meaning got bleached into 'answer' (cf. Icelandic andmcela 'oppose', composed of and-and mcela 'speak' from the noun mál 'speech, language'). The preserved material therefore suggests that *andwurdjan replaced *(and)swaran in Gothic and West-Germanic, and that this must have happened during prehistoric times. We assume, further, that the basic verb *wurdjan selected for the Nom-Acc case frame, in the meaning 'put into words', as it did in Old English and still does in Icelandic with the inherited orða 'put into words'. 
Let us now investigate the argument structure of *(and)swaran and *andwurdjan in Germanic. Both verbs select for a nominative subject and a dative object in all the early Germanic languages, and they still do in the languages that have preserved morphological case marking. In the languages that have lost case morphology accusative and dative have merged into a common object (oblique) form, which synchronically amounts to an accusative. The examples in (3) are with *(and)swaran and the ones in (4) are with *andwurdjan. ${ }^{2}$

Old English

(3a) him se yldesta andswarode (Beo. Th. 522)

him.DAT the oldest answered

'The oldest answered him'

Old Norse-Icelandic

(3b) vér svöruðum pér ok sögðum ... (Stj. 219, 2)

we answered you.DAT and said

'We answered you and said ...'

Old Danish (ca. 1425)

(3c) thæm scal han al ene swore (Skråer I.9 §9)

them.DAT shall he all one answer

'He shall answer them all alone'

Old Swedish

(3d) budit swardhe hanom swa (RK 2: 2545)

messenger answered him.DAT such

'The messenger answered him such'

Modern Icelandic

(3e) og hann svaraði henni til baka and he answered her.DAT to back 'and he answered her back'

2 The Gothic example (4a) is a translation from Greek, and the Old High German (4b) and the Old English (4e) ones are translations from Latin. In all these cases the Greek and Latin originals also have a dative with the verb 'answer' (see Section 3.3 below). 


\section{Modern Faroese}

$\left(3^{f}\right)$ at fáa svarað hvørjum sítt

to get answered each.DAT their.own

'to be able to answer each and every one about their own'

Modern Danish

(3g) Jeg svarede ham naturligvis ikke.

I answered him.ACC of.course not

'Of course I didn't answer him'

Modern Swedish

(3h) Kan dö lycklig nu för osciiii svarade mig can die happy now because Osciiii answered me.ACC

gånger två idag times two to.day

'Can die happy now since Osciiii answered me twice today'

Modern English

(3i) The girl answered him.

Gothic

(4a) bu hwas is, ei andwaurdjais guda?

you who are that reply.opt God.DAT

'Who are you replying to (OR: against) God?' (Rom 9:20)

Old High German

(4b) Tho antvvurtita imo Philippus

then answered him.DAT Philip.NOM

'Then Philip answered him' (Tatian, Ev. Harm., 8०.3)

Old Frisian

(4c) So ach him thi other andwerdia

then shall him.DAT the.Nom other.Nom answer

'Then the other must answer him' (The Skeltana Riucht Xxv)

Old Saxon

(4d) Imu anduuordidun frôlîco is friund angegin

him.DAT answered cheerfully his friends again

'His friends answered him cheerfully again' (Heliand 3041) 
Old English

(4e) Abraham hire andwerde

Abraham her.DAT answered

'Abraham answered her' (Gen. 16.6)

The correspondence set for * (and) swaran is given in Table 5.7 below, on the basis of which we suggest the reconstruction in Figure 5.3, where we reconstruct the original case frame as being Nom-Dat, and not Nom-Acc. This is because Nom-Dat is found in the earliest daughters, while Nom-Acc is not found until later stages of North and West Germanic and then only in languages where the morphological accusative and dative have merged, with subsequent functional merger of the two case uses.

TABLE 5.7 Predicate-specific correspondence set for the argument structure of Germanic *(and)swaran

ALT 1

Alt 2

Old English

NOM-DAT

Old Norse-Icelandic

NOM-DAT

Modern Icelandic

NOM-DAT

Modern Faroese

NOM-DAT

Modern English

NOM-ACC

Modern Swedish

NOM-ACC

Modern Danish

NOM-ACC

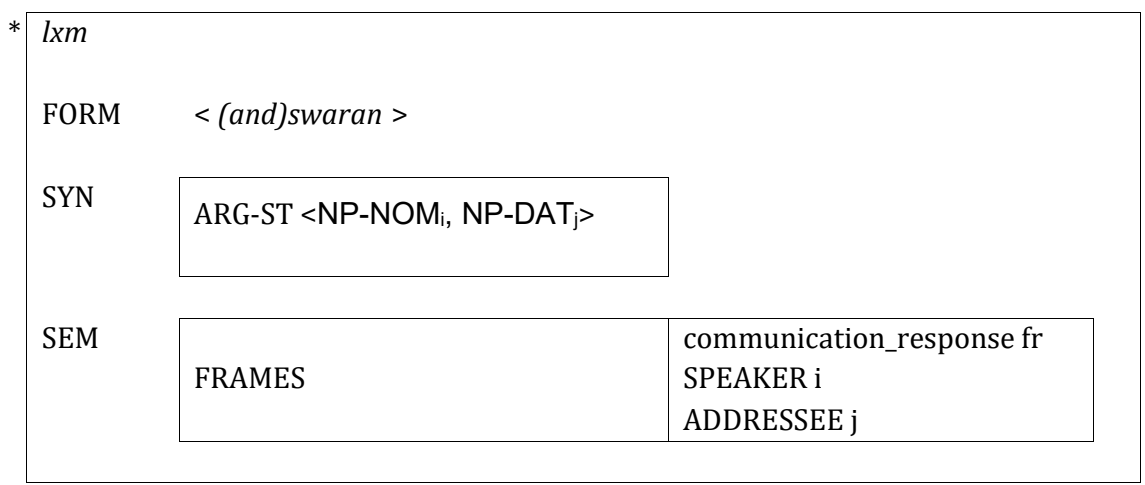

FIGURE 5.3 A reconstruction of the argument structure of 'answer' in Proto-Germanic 
To recapitulate, we propose that * (and)swaran is the older verb in Germanic meaning 'answer', and that it was replaced by *andwurdjan in East and West Germanic. This raises the question of where the Nom-Dat case frame of *andwurdjan came from. It is obvious that since *andwurdjan is a prefixed form of *wurdjan, which is derived from a noun, the case frame cannot be inherited from the source. The reason is that the noun *wurdan 'word' does not have a verbal argument structure and the argument structure of the verb *wurdjan was most likely Nom-Acc, as discussed above.

One question that arises is whether *andwurdjan may receive its case frame from the prefix and-, rather than from the synonymous *(and)swaran. This appears not to be the case. In a detailed study of the syntactic functions of prefixes in Old High German, for instance, Kuroda (2014) shows that valency is much less affected by prefixes in Old High German than in Modern German. Moreover, a case study of selected prefixed verbs in other Old Germanic languages confirms Kuroda's conclusions. For example, Go. andbindan 'untie' and its OE and OHG cognates, anbindan and intbintan, respectively, all select for accusative objects. Another example comes from Old Saxon, where the verb andbitan 'consume, partake' selects for a genitive object, illustrating beyond doubt that the dative with *andswaran and *andwurdian is not assigned by the prefix and-.

Earlier research on new verbs shows that four main tendencies are at work when new verbs are assigned case frames (Barðdal 1999, 2001, 2008, 2012):

- Case assignment by default

- Case frame borrowed with the lexical predicate it occurs with

- Case assignment inherited from a cognate source verb

- Case assignment on the basis of synonymous verbs

Default case assignment is the unmarked option and entails that a subject is assigned the nominative case and an object the accusative case, i.e. an analogical extension on the basis of the statistically most predominant pattern (cf. Barðdal 2011b). The second tendency entails that when a verb is borrowed from one language to another, it is borrowed with its case frame as well. This process has been documented in detail in a study of borrowed verbs in 15th century Icelandic (Barðdal 1999). The third tendency is typically found with verbs derived from already existing verbs, like Icelandic aðstoða 'assist' which is derived from its cognate stoða 'support' by means of the prefix $a$ - 'to'. The verb stoða selects for Nom-Acc in Icelandic, and it seems that aðstoða has simply inherited this case frame from its source. Another example is the Old English verb anbindan 'untie' mentioned above, which has presumably inherited its case from the unprefixed bindan 'bind, tie' which selects for Nom-Acc in all the Germanic languages. The fourth type of case assignment is found when a new verb receives case marking on the basis of an existing synonymous verb. This third type is quite common, as has been shown in research on Icelandic 
TABLE 5.8 Argument structure constructions with new verbs

Cognate verb source
Synonymous verb source

\begin{tabular}{llll}
\hline stoða 'support' & aðstoða 'assist & bjarga 'save' & redda 'save' \\
senda 'send' & símsenda 'fax' & laga 'fix' & ordna 'fix' \\
rita 'write' & afrita 'copy' & hringja 'phone' & bjalla 'phone' \\
fæera 'move' & uppfcera 'update' & daga 'dawn' & dona 'dawn' \\
pýða 'translate' & bakpýða 'decompile & skera 'cut' & kötta 'cut' \\
baka 'bake' & afbaka 'distort' & binda 'tie' & leisa 'lace' \\
skoða 'observe' & endurskoða 'audit' & hreinsa 'cleanse' & sjena 'make shiny' \\
skipta 'divide' & lagskipta 'stratify' & trufla 'bother' & bögga 'bug' \\
setja 'put' & gróðursetja 'plant' & eyða 'delete' & dilita 'delete' \\
\hline
\end{tabular}

(Barðdal 2001, 2008, 2012). Table 5.8 gives a few documented examples of case assignment of the latter two types (from Barðdal 2001, Appendix C), which are also most important for the present purposes.

Returning to *andwurdjan, it is clear that default case assignment is not responsible for its case frame, as default case assignment is Nom-Acc, and not Nom-Dat (see, for instance, Barðdal 2o11b on Icelandic). The second option is not relevant either since there is no reason to assume that *swaran has been borrowed into Germanic; it is formed from a PIE root *swer- 'speak', as all etymological dictionaries attest to, but has developed the specific meaning 'answer' within Germanic. With regard to the third option, the case frame cannot be inherited from a cognate source verb (cf. two leftmost columns in Table 5.8), since the cognate *wurdjan must be reconstructed with a Nom-Acc case frame. The most likely source of the case frame of *andwurdjan is thus that it comes from its synonymous verb *(and)swaran (cf. rightmost columns in Table 5.8). In other words, when *andwurdjan changed its meaning from 'put into words, speak' to 'answer' it also took over the case frame of the verb meaning 'answer', namely * (and) swaran.

The goal of this section has been to illustrate in detail how syntactic structures like, for instance, argument structure constructions may be reconstructed on the basis of cognate lexical verbs across daughter languages (cf. also Harris 2008; Barðdal \& Eythórsson 2012a, 2012b; Barðdal \& Smitherman 2013; Barðdal et al. 2013; Barðdal 2013, 2014; Eythórsson \& Barðdal 2016; Danesi, Johnson \& Barðdal 2017; Dunn et al. 2017; Johnson et al. 2019; Pooth et al. 2019; Vasques, Gonzales \& Barðdal 2019). The examples above, with 'think', 'thirst' and 'answer', deviate from the default Nom-Acc assignment in Germanic, and 
therefore involve at least some degree of arbitrariness in the mapping between the lexical verb and its case frame.

It is commonly assumed that all linguistic units which are not motivated synchronically must have an historical explanation. It is less widely recognized that this also applies to argument structure constructions. One could, however, argue that the dative subject case of 'think' is motivated synchronically by the fact that a subset of experiencer predicates exhibit that case frame. This relation, however, is not systematic, since experiencer predicates in Germanic may occur in the nominative and the accusative, as well as the dative. One could also argue that the dative object of 'answer' is motivated by the animacy of the object referent, as dative objects are often animate.

However, in a study of the productivity of different argument structure constructions, Barðdal (2008: 75) shows for Modern Icelandic that only $45 \%$ of dative objects are animate, while corresponding figures for accusative and genitive are $26 \%$ and $21 \%$, respectively. While languages like Modern German have more or less eliminated arbitrary case assignment from the language, with the consequence that dative as an object case is primarily used with animate objects (Wegener 1985; Primus 2012), this is not true for Icelandic, where arbitrary case assignment has been preserved to a much greater degree. Given that animate objects may be assigned dative, accusative or genitive, it appears that the exact linking between a specific lexical predicate with an animate object and its particular case frame is in part arbitrary. The verb *andwurdjan could therefore have been assigned the Nom-Acc or the Nom-Gen case frame, as well as the Nom-Dat case frame, if animacy was the decisive factor.

In this context, let us contemplate the issue of whether there is a difference between the concepts of "syntactic reconstruction" and what Klimov (1977) labels "diachronic interpretation". In other words, is it only possible to reconstruct on the basis of arbitrary correspondence sets? For instance, if all the early and archaic Indo-European daughter languages have a transitive construction with a nominative subject and an accusative object, is it then not legitimate to reconstruct such an argument structure for the proto-language, even though there certainly is little or no arbitrariness involved? Our answer to that question is an unequivocal yes.

Some might now argue that a transitive construction with a nominative subject and an accusative object is not specific for Proto-Indo-European, since such a construction is extremely common across languages. This raises the question whether typological considerations should prevent us from reconstructing on the basis of preserved material. Should we, for example, not reconstruct a $/ \mathrm{p} /$ for Proto-Indo-European because it is cross-linguistically common? The sound 
$/ \mathrm{p} /$ has certainly been identified in the earliest Indo-European languages on the basis of its occurrence in cognate words like 'father' and 'fish'. Since these lexical items have been inherited into the daughter languages, it is obvious that $/ \mathrm{p} /$ has also been inherited from an earlier proto-stage. On the basis of reconstructed words, the phonological system of Proto-Indo-European has been established (see, for example, Mayrhofer 1986), and the inventory of this reconstructed sound system uncontroversially contains $/ \mathrm{p} /$. Despite the fact that the sound $/ \mathrm{p} /$ is extremely common in the world's languages, Indo-Europeanists nevertheless confidently reconstruct it for Proto-Indo-European. The same would seem to apply to syntax.

One could now object even further and claim that a reconstruction of a Nom-Acc construction is banal. However, this is not a valid reason against such a reconstruction, as it is equally banal to say that Proto-Indo-European had a /p/ as it is to say that it had a transitive Nom-Acc construction. Thus, we conclude that a reconstruction on the basis of regularities is a legitimate enterprise, provided that this regularity is found in the daughter languages.

\subsection{Identification on the Basis of Cognate Structure}

One additional device to identify cognate argument structure constructions is through what Walkden calls the Double Cognacy Requirement (Walkden 2009, 2013). He points out that a sound, say /p/, cannot be reconstructed for Proto-Indo-European unless it is found in a cognate environment. To give an example, one cannot reconstruct /p/ on the basis of piscis 'fish' in Latin and fadar 'father' in Gothic. One has to reconstruct on the basis of piscis 'fish' in Latin and fisks 'fish' in Gothic, on the one hand, and on the basis of pater 'father' in Latin and fadar 'father' in Gothic, on the other. That is, a secure reconstruction is carried out on the basis of a cognate context, and not across cognate contexts.

Applying this requirement to argument structure, it is not only the lexical stem that may be cognate but also the case frame, and even the predicate structure. By case frame we mean valency patterns like Nom-Acc, Nom-Dat, Nom-Gen, Dat-Nom, Acc-Nom, Acc-Acc, Acc-Gen, etc. By predicate structure we refer to whether a verb is a simple verb, prefixed verb, compound verb, or a compositional predicate of some sort. As has already been discussed above, the case paradigms in Germanic are cognate; that is, the morphological markers in the case paradigms are inherited across the daughters. The case patterns themselves, i.e. the choice of subject and object case occurring together with a particular predicate, are also cognate, as evident from the fact that they are inherited into the daughters with the same lexical verbs (Barðdal \& Eythórsson 2012a, 2012b; Barðdal \& Smitherman 2013). 
Let us illustrate all this with the compositional predicate 'be good for' from all three branches of Germanic, with examples from Gothic, Old English and Old Norse-Icelandic:

Gothic

(5a) gop ist unsis her wisan
good is.3SG us.DAT here be.INF
'it is good for us to be here' (Luke 9:33)

Old English

(5b) betere is manna gehwylcum pæt him her on worulde better is.3SG men.GEN each.DAT that him here on world 'Every man has it better here in the world' (Ælfric Homily 28.107)

Old Norse-Icelandic

(5c) Betra er lifðum og sællifðum.

better is.3SG the.lived.DAT and the.well.lived.DAT

'Those who live and live well have it better.' (Hávámál 70)

The examples in (5) fulfil not only the Double Cognacy Requirement, they in fact instantiate triple cognacy. Double (or triple) cognacy follows from duality (or triality) of patterning. For instance, sounds are combined into word forms, and word forms are combined into sentences. In the case of argument structure: a) the lexical material is cognate, i.e. the verb 'be' and the adjective 'good/better'; b) the predicate structure is cognate, involving a compositional predicate consisting of 'be' and an adjective; and c) the case frame is also cognate, i.e. the subject is in the dative case. To concretize, lexical items are combined into predicate structure; case markers are combined into case patterns combining with argument structures; and finally, lexical items and predicate structure are combined into argument structure through a process merging lexical items with more schematic argument structure constructions. This is how a combination of factors involving cognate structure may contribute to the identification of cognates in syntax.

For a reconstruction of more schematic argument structure constructions, see Barðdal \& Smitherman (2013); Danesi, Johnson \& Barðdal (2017) and Vazquez Gonzalez \& Barðdal (2019), although it should be emphasized that the research program proposed here of identifying cognates does not of, course, rely on schematic reconstructions. On the contrary, it is based on substantive material being found instantiating the relevant argument structure constructions, as without substantive material, there can be no cognate lexical material. However, as we also emphasize above, lexical material is not always 
needed to identify cognates, as sometimes this can also be done on the basis of grammatical cognate material, like when case morphology is cognate or when predicate structure is cognate (see also Kikusawa, this volume, and Gildea \& Castro Alves, this volume).

Returning to the last discussion point in Section 3.1 above on reconstructing on the basis of regularity across the daughters, the question arises whether there is double cognacy in Nom-Acc argument structure constructions in the same sense as with compositional predicates. The case paradigms, here nominative and accusative, have already been reconstructed not only for Germanic but also for Proto-Indo-European (see, for example, Krahe 1969a, 1969b; Ringe 20o6; see also Pooth et al. 2019 for the emergence, development and reconstruction of the case frames in Proto-Indo-European). A reconstruction of the transitive Nom-Acc construction would therefore not only be carried out on the basis of the existence of an inherited Nom-Acc argument structure construction in the daughter languages, but also on the basis of the morphological nominative and the morphological accusative.

A few examples of cognate lexical verbs instantiating the Nom-Acc construction in the early Germanic languages are listed in Table 5.9, some of which are quite high on the transitivity scale (Hopper \& Thompson 1980). This means that not only is the case frame cognate, but also the lexical verbs. In fact, there are so many verbs that instantiate the Nom-Acc case frame, due to its property of being a default case pattern, assigned on the basis of analogical extensions of the statistically predominant pattern, that its reconstruction is almost banal, exactly as with the Proto-Indo-European /p/. However, exactly as with the Proto-Indo-European $/ \mathrm{p} /$, if one's intention is to reconstruct a grammatical system, both regular grammatical constructions and more idiosyncratic ones need to be reconstructed.

TABLE 5.9 Cognate Nom-Acc predicates in early Germanic

\begin{tabular}{llll}
\hline Gothic & Old English & Old Norse-Icelandic & Gloss \\
\hline dreiban & drïfan & drífa & 'drive' \\
maurprjan & myrðran & myrða & 'murder' \\
slahan & slean & slá & 'hit' \\
saggjan & senkan & sökkva & 'sink' \\
bairan & beran & bera & 'carry' \\
drigkan & drincan & drekka & 'drink' \\
itan & etan & eta & 'eat' \\
saihwan & sēon & sjá & 'see' \\
finpan & findan & finna & 'find' \\
& & & \\
\hline
\end{tabular}


One could perhaps now argue that a reconstruction of the Nom-Acc case frame may be less secure, exactly because it is the default pattern. That is, this case frame can easily arise through a change from another more marked case frame. This is indeed true; therefore such reconstruction must rely heavily on the quality of the co-occurrence patterns, i.e. on double cognacy, in that both the case frame and the relevant lexical verbs must be cognates across several branches. A change from a more marked case frame to a less marked or to the default case frame is not expected to take place with cognate verbs in language after language within a language family, unless of course there has been a massive development of such a type of change. Such massive developments, however, if they are not already known, may be established on the basis of the comparative material, i.e. by comparing cognate verb sets within languages of one branch. Therefore, reconstruction of default argument structure constructions is also possible, provided that the double cognacy requirement is fulfilled and the procedures of the Comparative Method honored.

Finally, with regard to changes in argument structure constructions, some of these are quite well known (Barðdal 2014), including regularization processes like Nominative Sickness, whereby nominative is substituted for oblique case with subjects (Eythórsson 2000, 2002; Jónsson \& Eythórsson 2005; Barðdal 2009, 2011a; Dunn et al. 2017). This process is found with both 'think' and 'thirst', discussed above, where dative and accusative have been replaced with a nominative, for instance in Modern German. In some of the other modern Germanic languages, like Modern English, Modern Swedish and Modern Dutch, this replacement happened through a different kind of process, namely the general loss of case morphology. Of course, a general loss of case morphology results in all argument structure constructions disappearing except for a generalized Nom-Acc construction, only visible with pronouns, thus distinguishing only between (nominative) subjects and (accusative) objects. As such, loss of case morphology constitutes the ultimate regularization process (cf. Barðdal 2009).

Processes resulting in the emergence of marked argument structure constructions have also been documented in the field. One such is Oblique Anticausativization, i.e. a process involving reduction in a verb's valency, first by creating synchronic correspondences between the oblique anticausative and its causative alternant, and then through the loss of the original causative alternant over time, leaving behind only the alternant with an oblique subject (Sandal 2011; Barðdal 2014; Barðdal et al. 2020). However, such a process of language change may also be detected through a rigorous investigation of the pre-stage. Any claims that there is lack of directionality in syntactic change are therefore unfounded when it comes to changes in argument structure constructions. 


\subsection{Identification on the Basis of Synonymous Material}

So far in this article, we have shown how Watkins' method can be applied to argument structure constructions, where we find cognate lexical items, cognate case paradigms, cognate case frames, and even cognate predicate structure. Our data, as yet, come from Germanic, which of course represents a fairly short time span, compared to, for instance, Proto-Indo-European.

Identifying cognate argument structure constructions on the basis of cognate lexical verbs may become increasingly difficult when the time span is longer than from the modern languages to the closest reconstructed intermediate node in the family tree, because of the well-known process of lexical substitution (Firth 1935; D'arcy 2006; Calude \& Pagel 2011; François 2011). An estimation of lexical replacement rates has been made by Pagel et al. (2007) and Pagel (2009) who suggest that the chances that a random cognate is replaced with a non-cognate word every $2,000-2,500$ years is $50 \%$, although this is highly dependent on frequency of use. That is, low-frequency words are replaced at a much faster rate and high-frequency words at a much slower rate.

Watkins (1995) certainly observes, in his work on poetic formulae, that with time, important content words are replaced, while the formula itself is maintained. This process has also been observed synchronically with idioms and set phrases (McGlone et al. 1994; Langlotz 20o6). Given these observations, in combination with our present knowledge of the acquisition of case frames by new predicates, we suggest that cognate argument structure constructions may be identified despite a deeper time span. This means that cognate argument structure constructions may be distinguished, not only because they share a lexical cognate, but also by virtue of being instantiated by a synonymous verb. In other words, since lexical predicates tend to be replaced with synonymous predicates through time, it is reasonable to assume that argument structure constructions remain stable although the lexical predicate itself is renewed.

To give an example, the verb 'answer' in the Modern Germanic languages has two cognate sets, reflexes of the etymons * (and)swaran and *andwurdjan. The facts discussed in Section 3.1 above suggest that ${ }^{*}$ (and)swaran is an earlier verb with this meaning, and that *andwurdjan replaced it in East and West Germanic. We also know that a verb meaning 'speak, put into words', usually selects for the Nom-Acc case frame in early Germanic, hence we assume that the Nom-Dat case frame with *andwurdjan in East and West Germanic must have been assigned to *andwurdjan on the basis of the case frame of * (and) swaran. This is an internal reconstruction, since this development had already taken place during prehistoric times.

Now, if English and the modern North Germanic languages had also lost the verb *(and)swaran, resulting in only one cognate set for 'answer', namely the 
modern reflexes of *andwurdjan, would we then not be in total ignorance of where its case frame came from? Our answer to that question is no, since we know that *andwurdjan takes a dative object by virtue of the fact that its predecessor, *(and)swaran, took a dative object. In other words, since argument structures stay the same, while their lexical predicates are replaced with synonymous lexemes, it becomes possible to identify cognate argument structure constructions through synonymous verbs. Therefore, not only cognate lexical verbs aid in identifying cognate argument structure constructions, but also non-cognate synonymous verbs.

Let us illustrate this for Proto-Indo-European, continuing with the verb 'answer':

Ancient Greek (Homer): hypokrinomai 'reply, answer'
(6a) hōs toi hypokrinontai
how you.DAT.SG answer.3PL
'... how they answer you.' (Homer, Iliad 7.407)

Ancient Greek (Attic): apokrinomai 'reply, answer'
(6b) egō gar autik' apokrinoumai soi
I for right.away will.answer.1SG you.DAT.SG clearly
'for I will presently answer you distinctly.' (Aristophanes, Clouds 1245)

Latin: respondeo 'reply, answer'
(6c) legatis respondit diem se ad deliberandum ambassadors.DAT answered.3SG day.ACC self to deliberate sumpturum
take
'He [Caesar] replied to the ambassadors, that he would take time to deliberate.' (Caesar, Gallic War 1.7)

Gothic: andwaurdjan 'answer'
(6d) pu hwas is, ei
andwaurdjais guda?
you who are that reply.2SG.OpT God.DAT
'Who are you replying to (or: against) God?' (Rom 9:20)

Old Russian: otvéčal- 'answer'
(6e) I Pskovъ
imb
otvécals
and Pskov.nom them.DAT replied.3SG
'And Pskov answered them.' (Pskovskaja letopis' Xvc) 
Old Lithuanian: atsakyti 'answer'

(6f) Ar šitaipo byskupui atsisakai?

do this bishop.DAT answer.2sG

'Do you answer the bishop in this manner?'

(Bretkunas Postille I372, y. 1591)

Hittite: āppa mema/i- 'speak/say back'

$\begin{array}{llll}\text { (6g) dUTU-uš } \quad A N A & \text { MUNUS.LUGAL } & \text { appa } & \text { memišta } \\ \text { sun.god-NOM DAT } & \text { queen } & \text { back } & \text { spoke.3SG } \\ \text { 'The Sun God replied to the queen.' (KBo 20.82 ii } & 33-34)\end{array}$

'The Sun God replied to the queen.' (KBo 20.82 ii 33-34)

Tocharian A: wätk- 'answer'

(6h) kupre ne säm penu sne tänklune wätkālts

if he PTCL without with difficulty confidence

wätkāṣș-äm ////

answers:3SG.CONJ-CL.OBL.PL

'If he responds to you without difficulty and with confidence' (YQ-14[II.5] b4)

Sanskrit: prati-brū- 'answer'

(6i) aprccham mātaram \ sā mā pratyabravīt

asked.3SG mother.ACc she.Nom me.ACC answered.3SG

'I asked my mother and she answered me' (Ch. 4.4.4)

The verb 'answer' takes Nom-Dat in all the earliest Indo-European languages in (6) above except for Sanskrit, where it takes a Nom-Acc. While Sanskrit is one of the oldest documented Indo-European languages, it is known to have innovated in some respects, for instance in the vowel system which has been simplified drastically (see, for example, Mayrhofer 1978). It also seems, on a comparison with the other early Indo-European languages, that predicates selecting for non-nominative subject-like arguments have been significantly reduced (cf. Danesi 2014). It is also well known that the accusative as an object case has heavily invaded the space of the dative in Sanskrit. Most importantly, however, for this example, the accusative is most likely governed by the prefix prati-(Leonid Kulikov, p.c.). It is therefore very likely that the accusative object of 'answer' is an innovation in Sanskrit.

Going systematically through the verbs in (6), the case marking of the addressee in Tocharian is ambiguous, as the clitic -äm is a general oblique form that does not distinguish between accusative, dative and the genitive, as is shown in the correspondence set in Table 5.10. The Latin, the Old Lithuanian 
and the Hittite verbs might possibly have inherited the dative case of the addressee from their corresponding base verbs, as the unprefixed spondeo in Latin means 'promise', the unprefixed sakyti in Old Lithuanian means to 'say', and the simple mema/i- in Hittite means to 'speak'. Verbs having these meanings tend to assign dative case to the addressee in the Indo-European languages.

The situation is different with verbs like the unprefixed krinomai in Ancient Greek which is highly polysemous, instantiating meanings like 'judge', 'choose' and even 'distinguish'. With all three of these meanings, the object occurs in the accusative case and not in the dative. The Old Russian, otvéčal-, does not have an unprefixed counterpart, but with the prefix pre-, it means 'welcome' or 'receive in a friendly way', selecting for an accusative object. The same is true for the unprefixed Gothic *waurdjan 'put into words', selecting for an accusative object, as already discussed in Section 3.1 above. Thus, the Greek, Slavic and Germanic data exclude an analysis involving case and argument structure assignment on the basis of cognate stems already existing in the language, while the Baltic, Italic and Anatolian data are compatible with either analysis, i.e. either case and argument structure has been assigned on the basis of already existing cognate verb stems or on the basis of synonymous verbs.

Hence, on the basis of synonymous material from at least three branches of Indo-European, Greek, Slavic and Germanic, we reconstruct Nom-Dat as the predicate-specific argument structure construction of 'answer' in Proto-Indo-European, cf. the correspondence sets in Table 5.10 and the partial reconstruction in Figure 5.4.

TABLE 5.10 Predicate-specific correspondence set for the argument structure of a ProtoIndo-European verb meaning 'answer'

\begin{tabular}{llll}
\hline & Alt. 1 & Alt. 2 & Alt. 3 \\
\hline Ancient Greek & NOM-DAT & & \\
Latin & NOM-DAT & & \\
Gothic & NOM-DAT & & \\
Old Russian & NOM-DAT & & NOM-GEN \\
Old Lithuanian & NOM-DAT & & \\
Hittite & NOM-DAT & & \\
Tocharian B & NOM-DAT & NOM-ACC & \\
Sanskrit & & NOM-ACC & \\
\end{tabular}




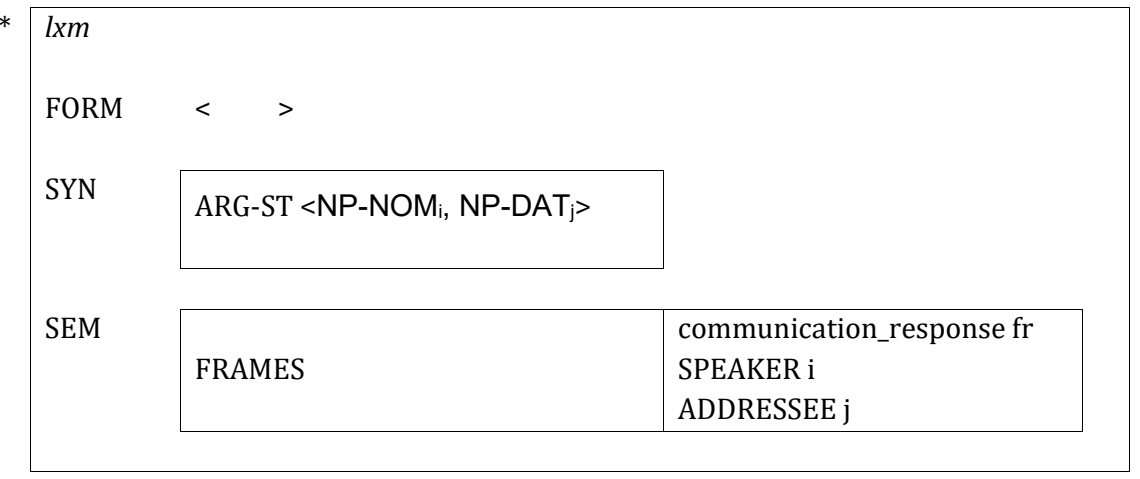

FIGURE 5.4 A reconstruction of the argument structure of 'answer' in Proto-Indo-European

The reconstruction in Figure 5.4 is partial because the field for the lexical verb is empty, i.e. it does not contain any phonological material. In other words, this reconstruction is a reconstruction of the verb-specific argument structure construction Nom-Dat for a verb with the meaning 'answer' in Proto-Indo-European. While we do not know the form of the verb, we posit, on the basis of a comparison between the daughters, that a verb with this meaning must have instantiated a Nom-Dat case frame in Proto-Indo-European. The identification of this verb-specific argument structure construction is based on non-cognate synonymous predicates across the daughters, and not on a cognate lexical item. This reconstruction is certainly more schematic than traditional reconstructions based on cognate lexical material. It is nevertheless based on a known linguistic process, in which predicates get replaced by their synonyms in the course of time, while simultaneously maintaining their original argument structure constructions.

Let us consider one final example with an even more exceptional case frame, namely the Dat-Gen frame. Several Indo-European daughter languages, from at least four different branches, exhibit a predicate meaning 'lack, need' which occurs with this case frame (see also Frotscher, Kroonen \& Barðdal 2020). The examples below are from Ancient Greek, Gothic, Old Russian and Lithuanian:

Ancient Greek (prosdéó 'need')

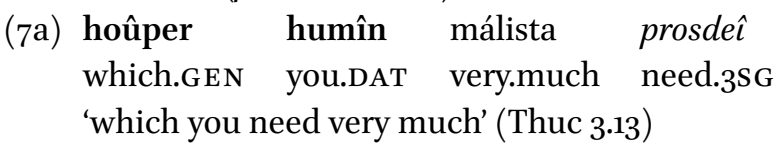


Gothic (wan ist 'is lacking')

(7b) ainis pus wan ist one.GEN you.DAT lacking is.3sg 'you lack one thing' (Mk 10.21)

Old Russian (lixyi 'lack')

(7c) Zenice bo ne imy lixz jestb světa pupil.ACC because.PTCL NEG them.DAT lacking be.3sg light.GEN 'they are not lacking light in their eyes'

(Pandekt Antioxa po spisku XI veka)

Lithuanian (trūkti 'lack')

$\begin{array}{lll}\text { (7d) Jam } & \text { trūksta } & \text { kantrybės } \\ \text { he.DAT } & \text { lacks.3SG } & \text { patience.GEN } \\ \text { 'He lacks patience' } & \end{array}$

In our view, the data in (7) motivate a reconstruction of a predicate in Proto-Indo-European with the meaning 'lack, need', as sufficiently established with data from four different branches. Such a reconstruction would be only partial, exactly as the reconstruction of 'answer' in Proto-Indo-European in Figure 5.4 above, with no phonological material. The reconstruction would be of a purely schematic argument structure construction containing the Dat-Gen case frame and the meaning lack, need'. As with 'answer' above, this reconstruction would be based on synonymous lexical material and not on cognate lexical material.

Furthermore, not only are partial reconstructions of predicates and their argument structures possible, as we have just demonstrated (cf. also Barðdal \& Eythórsson 2012a; Barðdal \& Smitherman 2013; see also Vazquez Gonzalez \& Barðdal 2019 for a reconstruction of a verb-class-specific argument structure construction), but the discovery of the important developmental path whereby lexical predicates get replaced by their synonyms, while case frames are maintained, makes certain predictions in a wider historical linguistic context. One such prediction is that lexical semantic verb classes will be linked to the same argument structure constructions across time, provided of course that the case and alignment system stays more or less intact, and hence that argument structure constructions are reconstructable as such for earlier protostages on the basis of lexical semantic verb classes alone (cf. Barðdal 2007; Barðdal et al. 2011; Barðdal et al. 2012). In other words, this is a force for conservatism, maintaining irregularity. In this way, the insights inherent in Watkins' legacy that morphological material may be used for reconstructing abstract 
syntactic units are taken one step further, potentially yielding a substantial improvement in the methodology of linguistic reconstruction.

\section{Summary}

The Comparative Method in historical linguistics has been successfully employed in reconstructing phonological, morphological and lexical units, not only by the Neogrammarians in the late 19th and early 2oth centuries, but further into modern times. Syntactic reconstruction, in contrast, has been regarded as a precarious enterprise, an unreliable exercise, and fraught with pitfalls at every stage.

As a reaction to three different attempts at reconstructing basic word order for Proto-Indo-European, Watkins' paper from 1976 was hugely influential in the general renouncing of syntactic reconstruction. The first of these three attempts was done on the basis of Greenberg's universals, the second on the basis of word order frequencies in Homeric Greek, and the third one on the basis of the word orders attested in the early daughters. It was not until nearly 20 years later, however, in his 1995 book on Indo-European poetics, that Watkins properly proposed a research program which opened up new vistas for syntactic reconstruction, showcasing his method with an investigation of cognate dragon myths across the early Indo-European daughter languages. The core of Watkins' proposal lies in carrying out syntactic reconstruction through morphological devices, utilizing common morphosyntactic material as a means of identifying cognates. Watkins' work on poetic formulae shows how layers of cognate collocations and prefabs can be identified through morphological clues, together with important fragments of syntax from earlier periods of the Indo-European languages, which are reconstructable as such.

We maintain that the ability to reconstruct all of morphosyntax should by no means be considered insignificant. Moreover, the area of syntactic research which we have mostly concentrated on, that is, case and argument structure constructions, constitutes in itself a major subfield within syntactic research and syntactic theorizing. Launching a research program into how to reconstruct argument structure constructions is therefore no insignificant task, in a scientific atmosphere that has, for almost four decades, been engulfed with despondency over the perceived failure of syntactic reconstruction.

As a part of this research program, we have demonstrated how cognate argument structure constructions may be identified, with the aid of a) the lexical predicates that instantiate them, b) cognate case frames, c) cognate predicate structures, and d) cognate case morphology. For this purpose we 
have compared case and argument structure constructions of three Germanic verbs, 'think', 'thirst', and 'answer', all of which have a case frame that deviates from the canonical Nom-Acc frame, and hence exhibits a certain degree of arbitrariness. The directionality of the changes is in part retrievable from documented processes and is in part revealed by a proper scrutiny of the datasets themselves.

However, we do not stop at that; our aim here has been to bring Watkins' research program one step further, and to show how cognate argument structure constructions may be identified on the basis of non-cognate synonymous predicates. This claim is based on documented processes of how new verbs acquire their case and argument structure constructions, of which one major process involves new verbs attracting case frames on analogy to already existing synonymous verbs. We have thus illustrated how cognate argument structure constructions may be identified using non-cognate lexical material through two case studies. The first involves the verb 'answer' which has two cognate sets in Germanic, but at least eight sets across Indo-European. This larger number of cognate sets is expected, given the greater time depth for Proto-Indo-European than for Proto-Germanic, and given our current knowledge of the speed of lexical replacement. We have reconstructed a predicatespecific argument structure construction, Nom-Dat, for Proto-Indo-European, on the basis of the evidence provided by synonymous predicates in the early daughters.

In our second case study, we have examined the verb 'lack, need', occurring with the Dat-Gen case frame and with synonymous non-cognate lexical material only, from four different branches of Indo-European, again illustrating the viability of this method. Ultimately, we argue that semantic spaces can be reconstructed for argument structure constructions at earlier proto-stages, on the basis of lexical-semantic verb classes, since argument structure constructions may remain stable while lexical items are replaced. In this way, Watkins' program can be taken one step further, from reconstructing on the basis of cognate lexical material to reconstructing on the basis of non-cognate synonymous material.

\section{References}

Adger, David. 2003. Core Syntax: A Minimalist Approach. Oxford: Oxford University Press.

Allen, Cynthia L. 1995. Case Marking and Reanalysis: Grammatical Relations from Old to Modern English. Oxford: Oxford University Press. 
Barðdal, Jóhanna. 1999. Case and Argument Structure of some Loan Verbs in $15^{\text {th }}$ Century Icelandic. Alla tiders språk. En Vänskrift till Gertrud Pettersson november 1999, ed. by Inger Haskå \& Carin Sandqvist, 9-23. Lundastudier i Nordisk språkvetenskap A 55. Lund: Institutionen för nordiska språk.

Barðdal,Jóhanna. 2000. Oblique Subjects in Old Scandinavian. NOWELE:North-Western European Language Evolution 37: 25-51.

Barðdal, Jóhanna. 2001. Case in Icelandic - A Synchronic, Diachronic and Comparative Approach. Lundastudier i Nordisk språkvetenskap A 57. Lund: Department of Scandinavian Languages.

Barðdal, Jóhanna. 2007. The Lexical and Semantic Range of the Ditransitive Construction in the History of (North) Germanic. Functions of Language 14(1): 9-30. Barðdal, Jóhanna. 2008. Productivity: Evidence from Case and Argument Structure in Icelandic. Amsterdam: John Benjamins.

Barðdal, Jóhanna. 2009. The Development of Case in Germanic. The Role of Semantic, Pragmatic, and Discourse Factors in the Development of Case, ed. by Jóhanna Barðdal \& Shobhana L. Chelliah, 123-159. Amsterdam: John Benjamins.

Barðdal, Jóhanna. 2011a. The Rise of Dative Substitution in the History of Icelandic: A Diachronic Construction Grammar Account. Lingua 121(1): 6o-79.

Barðdal, Jóhanna. 2onb. Lexical vs. Structural Case: A False Dichotomy. Morphology $21(3-4)$ : 619-659.

Barðdal, Jóhanna. 2012. Predicting the Productivity of Argument Structure Constructions. Berkeley Linguistics Society 32(2006): 467-478.

Barðdal, Jóhanna. 2013. Construction-Based Historical-Comparative Reconstruction. The Oxford Handbook of Construction Grammar, ed. by Greame Trousdale \& Thomas Hoffmann, 438-457. Oxford: Oxford University Press.

Barðdal, Jóhanna. 2014. Syntax and Syntactic Reconstruction. The Routledge Handbook of Historical Linguistics, ed. by Claire Bowern \& Bethwyn Evans, 343-373. London: Routledge.

Barðdal, Jóhanna, Valgerður Bjarnadóttir, Serena Danesi, Tonya Kim Dewey, Thórhallur Eythórsson, Chiara Fedriani \& Thomas Smitherman. 2013. The Story of 'Woe'. Journal of Indo-European Studies 41(3-4): 321-377.

Barðdal, Jóhanna \& Thórhallur Eythórsson. 2003. The Change that Never Happened: The Story of Oblique Subjects. Journal of Linguistics 39(3): 439-472.

Barðdal, Jóhanna \& Thórhallur Eythórsson. 2012a. Reconstructing Syntax: Construction Grammar and the Comparative Method. Sign-Based Construction Grammar, ed. by Hans C. Boas \& Ivan A. Sag, 257-308. Stanford: CSLI Publications.

Barðdal, Jóhanna \& Thórhallur Eythórsson. 2012b. "Hungering and Lusting for Women and Fleshly Delicacies”: Reconstructing Grammatical Relations for Proto-Germanic. Transactions of the Philological Society $110(3): 363-393$. 
Barðdal, Jóhanna, Kristian E. Kristoffersen \& Andreas Sveen. 2011. West Scandinavian Ditransitives as a Family of Constructions: With a Special Attention to the Norwegian V-REFL-NP Construction. Linguistics 49(1): 53-104.

Barðdal, Jóhanna \& Leonid Kulikov. 20o9. Case in Decline. The Oxford Handbook of Case, ed. by Andrej Malchukov \& Andrew Spencer, 470-477. Oxford: Oxford University Press.

Barðdal, Jóhanna, Leonid Kulikov, Roland Pooth \& Peter Alexander Kerkhof. 2020. Oblique Anticausatives: A Morphosyntactic Isogloss in Indo-European. To appear in a special issue on "Morphological Isoglosses in Indo-European" in Poznan Studies in Contemporary Linguistics.

Barðdal, Jóhanna \& Thomas Smitherman. 2013. The Quest for Cognates: A Reconstruction of Oblique Subject Constructions in Proto-Indo-European. Language Dynamics and Change 3(1): 28-67.

Barðdal, Jóhanna, Thomas Smitherman, Valgerður Bjarnadóttir, Serena Danesi, Gard B. Jenset \& Barbara McGillivray. 2012. Reconstructing Constructional Semantics: The Dative Subject Construction in Old Norse-Icelandic, Latin, Ancient Greek, Old Russian and Old Lithuanian. Studies in Language 36(3): 511-547.

Bauer, Brigitte L. M. 200o. Archaic Syntax in Indo-European: The Spread of Transitivity in Latin and French. Berlin: Mouton de Gruyter.

Boas, Hans C. 2003. A Constructional Approach to Resultatives. Stanford: CSLI Publications.

Bowern, Claire. 2008. Syntactic Change and Syntactic Reconstruction in Generative Grammar. Principles of Syntactic Reconstruction, ed. by Gisela Ferraresi \& Maria Goldbach, 187-216. Amsterdam: John Benjamins.

Brugmann, Karl. 1913. Zu den Ablautverhältnissen der sogenannten starken Verba des Germanischen. Indogermanische Forschungen 32: 179-195.

Calude, Andreea S. \& Mark Pagel. 2011. How Do We Use Language? Shared Patterns in the Frequency of Word Use across 17 World Languages. Philosophical Transactions of the Royal Society B 366: 1101-1107.

Campbell, Lyle \& Alice C. Harris. 2003. Syntactic Reconstruction and Demythologizing 'Myth and the Prehistory of Grammars'. Journal of Linguistics 38: 599-618.

Campbell, Lyle \& Marianne Mithun. 1980. The Priorities and Pitfalls of Syntactic Reconstruction. Folia Linguistica Historica 1: 19-40.

Comrie, Bernard. 1980. Morphology and Word Order Reconstruction: Problems and Prospects. Historical Morphology, ed. by Jacek Fisiak, 83-96. The Hague: Mouton.

Croft, William. 2001. Radical Construction Grammar: Syntactic Theory in Typological Perspective. Oxford: Oxford University Press.

Croft, William. 2009. Connecting Frames and Constructions: A Case Study of "eat" and "feed". Constructions and Frames 1: 7-28.

Croft, William \& D. Alan Cruse. 2004. Cognitive Linguistics. Cambridge: Cambridge University Press. 
Danesi, Serena. 2014. Accusative Subjects in Avestan: 'Errors' or Noncanonically Marked Arguments. Indo-Iranian Journal 57(3): 223-26o.

Danesi, Serena, Cynthia A. Johnson \& Jóhanna Barðdal. 2017. Between the Historical Languages and the Reconstructed Language: An Alternative Approach to the Gerundive + "Dative of Agent" Construction in Indo-European. Indogermanische Forschungen 122: 143-188.

Daniels, Don. 2015. A Reconstruction of Proto-Sogeram: Phonology, Lexicon, and Morphosyntax. University of California, Santa Barbara, Ph.D. dissertation.

Daniels, Don. 2017. A Method for Mitigating the Problem of Borrowing in Syntactic Reconstruction. Studies in Language 41(3): 577-614.

D’arcy, Alexandra. 2006. Lexical Replacement and the Like(s). American Speech 81(4): 339-357.

Delbrück, Berthold. 1878. Die altindische Wortvolge aus dem Çatapathabrāhmana dargestellt (Syntaktische Forschungen III). Halle: Verlag des Waisenhauses.

Dunn, Michael, Tonya Kim Dewey, Carlee Arnett, Thórhallur Eythórsson \& Jóhanna Barðdal. 2017. Dative Sickness: A Phylogenetic Analysis of Argument Structure Evolution in Germanic. Language 93(1): e1-e22.

Eythórsson, Thórhallur. 200o. Dative vs. Nominative: Changes in Quirky Subjects in Icelandic. Leeds Working Papers in Linguistics 8: 27-44.

Eythórsson, Thórhallur. 2002. Changes in Subject Case Marking in Icelandic. Syntactic Effects of Morphological Change, ed. by David Lightfoot, 196-212. Oxford: Oxford University Press.

Eythórsson, Thórhallur \& Jóhanna Barðdal. 2005. Oblique Subjects: A Common Germanic Inheritance. Language 81(4): 824-881.

Eythórsson, Thórhallur \& Jóhanna Barðdal. 2011. Die Konstruktionsgrammatik und die komparative Methode. Indogermanistik und Linguistik im Dialog: Akten der XIII. Fachtagung der Indogermanischen Gesellschaft vom 21. bis 27. September 2008 in Salzburg, ed. by Thomas Krisch \& Thomas Lindner, 148-156. Wiesbaden: Reichert Verlag.

Eythórsson, Thórhallur \& Jóhanna Barðdal. 2016. Syntactic Reconstruction in IndoEuropean: The State of the Art. Franz Bopp and his Comparative Grammar Model (1816-2016), ed. by J. Gorrochategui, C. García Castillero \& J. M. Vallejo. A special monographic volume in Veleia 33: 83-102.

Falk, Cecilia. 1997. Fornsvenska upplevarverb [Old Swedish Experiencer Verbs], Lund: Lund University Press.

Ferraresi, Gisella \& Maria Goldbach (eds.). 2008. Principles of Syntactic Reconstruction. Amsterdam: John Benjamins.

Fillmore, Charles J. 1982. Frame Semantics. Linguistics in the Morning Calm, ed. by the Linguistic Society of Korea, 111-138. Seoul: Hanshin.

Fillmore, Charles J. 1985. Frames and the Semantics of Understanding. Quaderni di Semantica 6(2): 222-254. 
Fillmore, Charles J. \& Collin F. Baker. 20o9. A Frames Approach to Semantic Analysis. The Oxford Handbook of Linguistic Analysis, ed. by Bernd Heine \& Heiko Narrog, 313-339. Oxford: Oxford University Press.

Fillmore, Charles J., Paul Kay \& Mary Catherine O'Connor. 1988. Regularity and Idiomaticity in Grammatical Constructions: The Case of Let Alone. Language 64: 501-538.

Firth, J. R. 1935. The Technique of Semantics. Transactions of the Philological Society 34(1): $3^{6-73 .}$

Fox, Anthony. 1995. Linguistic Reconstruction: An Introduction to Theory and Method. Cambridge: Cambridge University Press.

François, Alexandre. 2011. Social Ecology and Language History in the Northern Vanuatu Linkage: A Tale of Divergence and Convergence. Journal of Historical Linguistics 1(2): 175-246.

Fried, Mirjam. 2015. Irregular Morphology in Regular Syntactic Patterns: A Case of Constructional Re-Alignment. Diachronic Construction Grammar, ed. by Jóhanna Barðdal, Spike Gildea, Elena Smirnova \& Lotte Sommerer, 141-174. Amsterdam:John Benjamins.

Fried, Mirjam \& Jan-Ola Östman. 2005. Construction Grammar and Spoken Language: The Case of Pragmatic Particles. Journal of Pragmatics 37(11): 1752-1778.

Friedrich, Paul. 1975. Proto-Indo-European Syntax: The Order of Meaningful Elements. (Journal of Indo-European Studies Monograph 1.) Washington, D.C.: Institute for the Study of Man.

Frotscher, Michael, Guus Kroonen \& Jóhanna Barðdal. 2020. Indo-European Inroads into the Syntactic-Etymological Interface: A Reconstruction of the PIE Verbal Root *menk ${ }^{w_{-}}$'lack' and its Argument Structure. Submitted.

Gildea, Spike. 1998. On Reconstructing Grammar: Comparative Cariban Morphosyntax. Oxford: Oxford University Press.

Gildea, Spike. 20oo. On the Genesis of the Verb Phrase in Cariban Languages. Reconstructing Grammar: Comparative Linguistics and Grammaticalization, ed. by Spike Gildea, 65-106, Amsterdam: John Benjamins.

Goldberg, Adele E. 1995. Constructions: A Construction Grammar Approach to Argument Structure. Chicago: University of Chicago Press.

Goldberg, Adele E. 20o6. Constructions at Work: The Nature of Generalization in Language. Oxford: Oxford University Press.

Harris, Alice C. 2008. Reconstruction in Syntax: Reconstruction of Patterns. Principles of Syntactic Reconstruction, ed. by Gisella Ferraresi \& Maria Goldbach, 73-95. Amsterdam: John Benjamins.

Harris, Alice C. \& Lyle Campbell. 1995. Historical Syntax in Cross-Linguistic Perspective. Cambridge: Cambridge University Press.

Harrison, S. P. 2003. On the Limits of the Comparative Method. The Handbook of Historical Linguistics, ed. by Brian D. Joseph \& Richard D. Janda, 343-368. Oxford: Blackwell. 
Hoenigswald, H. M. 1978. The Annus Mirabilis 1876 and Posterity. Transactions of the Philological Society $76: 17-35$.

Holland, Gary. 2003. Syntactic Reconstruction. The International Encyclopedia of Linguistics, 2nd edition, ed. by William Frawley, Vol. 3, 448-45o. Oxford: Oxford University Press.

Hopper, Paul \& Sandra A. Thompson. 1980. Transitivity in Grammar and Discourse. Language 56: 251-299.

Jeffers, Robert J. 1976. Syntactic Change and Syntactic Reconstruction. Current Progress in Historical Linguistics: Proceedings of the Second International Conference on Historical Linguistics, ed. by William M. Christie, Jr. (ed.), 1-15. Amsterdam: North-Holland Publishing.

Jespersen, Otto. 1927. A Modern English Grammar on Historical Principles, Vol. 3. Heidelberg: Winter.

Johnson, Cynthia A., Peter Alexander Kerkhof, Leonid Kulikov, Esther Le Mair \& Jóhanna Barðdal. 2019. Argument Structure, Conceptual Metaphor and Semantic Change: How to Succeed in Indo-European without Really Trying. Diachronica 36(4): 463-508.

Jónsson, Jóhannes Gísli. 2003. Not so Quirky: On Subject Case in Icelandic. New Perspectives in Case Theory, ed. by Ellen Brandner \& Heike Zinsmeister, 127-163. Stanford: CSLi Publications.

Jónsson, Jóhannes Gísli \& Thórhallur Eythórsson. 2005. Variation in Subject Case Marking in Insular Scandinavian. Nordic Journal of Linguistics 28(2): 223-245.

Kay, Paul \& Charles J. Fillmore. 1999. Grammatical Constructions and Linguistic Generalizations: The What's X doing Y? Construction. Language 75(1): 1-33.

Kikusawa, Ritsuko. 2002. Proto Central Pacific Ergativity: Its Reconstruction and Development in the Fïian, Rotuman and Polynesian languages. Canberra: Pacific Linguistics.

Kikusawa, Ritsuko. 2003. The Development of Some Indonesian Pronominal Systems. Historical Linguistics 2001: Selected Papers from the 15th International Conference on Historical Linguistics, Melbourne, 13-17 August 2001, ed. by Barry J. Blake, Kate Burridge \& Jo Taylor, 237-268. Amsterdam: John Benjamins.

Klein, Jared S. 2010. Review of Principles of Reconstruction, ed. by Gisela Ferraresi \& Maria Goldbach (2008). Language 86: 720-726.

Klimov, G[eorgiī] A[ndreevich]. A. 1977. Tipologija jasykov aktivnogo stroja [The Typology of Active Languages]. Moscow: Nauka.

Kluge, Friedrich. 2002. Etymologisches Wörterbuch der deutschen Sprache, 24th edition, by Elmar Seebold. Berlin: Walter de Gruyter.

Krahe, Hans. 1969a. Germanische Sprachwissenschaft, Vol. 3: Wortbildungslehre. $7^{\text {th }}$ edition. Berlin: Walter de Gruyter.

Kroonen, Guus. 2013. Etymological Dictionary of Proto-Germanic. Leiden: Brill 
Krahe, Hans. 1969b. Indogermanische Sprachwissenschaft, Vol. 2: Formenlehre. Berlin: Walter de Gruyter.

Kulikov, Leonid \& Nikolaos Lavidas (eds.). 2013. Proto-Indo-European Syntax and its Development, a guest-edited issue in Journal of Historical Linguistics 3(2): 1-152.

Kuroda, Susumu. 2014. Die Syntaktische Funktion der Präfigierung Im Althochdeutschen. Heidelberg: Winter.

Langlotz, Andreas. 20o6. Idiomatic Creativity: A Cognitive Linguistic Model of Idiom-Representations and Idiom-Variation in English. Amsterdam: John Benjamins.

Lehmann, Winfred P. 1974. Proto-Indo-European Syntax. Austin: University of Texas Press.

Lightfoot, David W. 1979. Principles of Diachronic Syntax. Cambridge: Cambridge University Press.

Lightfoot, David W. 2002a. Myths and the Prehistory of Grammars. Journal of Linguistics 38(1): $113^{-136 .}$

Lightfoot, David W. 2002b. More Myths. Journal of Linguistics 38(3): 619-626.

Lightfoot, David W. 2006. How New Languages Emerge. Cambridge: Cambridge University Press.

Luraghi, Silvia. 1987. Patterns of Case Syncretism in Indo-European Languages. Papers from the VIIth International Conference on Historical Linguistics, ed. by Anna G. Ramat, Onofrio Carruba \& Guiliano Bernini, 355-377. Amsterdam: John Benjamins. Mayrhofer, Manfred. 1978.Sanskrit-GrammatikmitsprachvergleichendenErläuterungen. Berlin: Walter de Gruyter.

Mayrhofer, Manfred. 1986. Indogermanische Grammatik, Volume 1: Lautlehre. Heidelberg: Winter.

McGlone, Matthew S., Sam Glucksberg \& Christina Cacciari. 1994. Semantic Productivity and Idiom Comprehension. Discourse Processes 17: 167-19o.

Mendoza,Julia. 1998. Syntaxis. Manual de Lingüística Indoeuropea II I, ed. by Francisco R. Adrados, Alberto Bernabé \& Julia Mendoza, 141-246. Madrid: Ediciones Clásicas.

Mengden, Ferdinand von. 20o8. Reconstructing Complex Structures: A Typological Perspective. Principles of Syntactic Reconstruction, ed. by Gisella Ferraresi \& Maria Goldbach, 97-119. Amsterdam: John Benjamins.

Michaelis, Laura A. 2009. Sign-based Construction Grammar. The Oxford Handbook of Linguistic Analysis, ed. by Bernd Heine \& Heiko Narrog, 155-176. Oxford: Oxford University Press.

Michaelis, Laura A. 2012. Making the Case for Construction Grammar. Sign-Based Construction Grammar, ed. by Hans C. Boas \& Ivan A. Sag, 31-68. Stanford: CSLI Publications.

Michaelis, Laura A. \& Josef Ruppenhofer. 2001. Beyond Alternations: A Constructional Model of the German Applicative Pattern. Stanford: CSLI Publications.

Miller, D. Gary. 1975. Indo-European: vso, sov, svo, or all three? Lingua 37: 31-52. 
Miranda, Rocky. 1976. Comments on Jeffers. Current Progress in Historical Linguistics: Proceedings of the Second International Conference on Historical Linguistics, ed. by William M. Christie, Jr., 12-14. Amsterdam: North-Holland Publishing.

Nichols, Johanna. 2008. Why Are Stative-Active Languages Rare in Eurasia? A Typological Perspective on Split Subject Marking. The Typology of Semantic Alignment, ed. by Mark Donohue \& Søren Wichmann, 121-139. Oxford: Oxford University Press.

Pagel, Mark. 2009. Human Language as a Culturally Transmitted Replicator. Nature Reviews Genetics 10: 405-415.

Pagel, Mark, Quentin D. Atkinson \& Andrew Meade. 2007. Frequency of Word-Use Predicts Rates of Lexical Evolution throughout Indo-European History. Nature 449: 717-720.

Petruck, Miriam. 1996. Frame Semantics. Handbook of Pragmatics, ed. by J. Verschueren, J-O Östman, J. Blommaert \& C. Bulcaen, 1-13. Amsterdam: John Benjamins.

Pires, Acrisio \& Sarah G. Thomason. 2008. How Much Syntactic Reconstruction is Possible? Principles of Syntactic Reconstruction, ed. by Gisela Ferraresi \& Maria Goldbach, 27-72. Amsterdam: John Benjamins.

Primus, Beatrice. 2012. Semantische Rollen. Heidelberg: Carl Winter.

Ringe, Don. 2006. From Proto-Indo-European to Proto-Germanic. Oxford: Oxford University Press.

Roberts, Ian. 2007. Diachronic Syntax. Oxford: Oxford University Press.

Rögnvaldsson, Eiríkur. 1991. Quirky subjects in Old Icelandic. Papers from the Twelfth Scandinavian Conference of Linguistics, ed. by Halldór Á. Sigurðsson, 369-378. Reykjavík: Institute of Linguistics, University of Iceland.

Rögnvaldsson, Eiríkur. 1995. Old Icelandic: A Non-Configurational Language? NOWELE: North-Western European Language Evolution 26: 3-29.

Sag, Ivan. 2012. Sign-Based Construction Grammar: An Informal Synopsis. Sign-Based Construction Grammar, ed. by Hans C. Boas \& Ivan A. Sag, 69-2O2. Stanford: CSLI Publications.

Sandal, Catrine. 2011. Akkusative subjekt og antikausativitet i norrønt [Accusative Subjects and Anticausativization in Old Norse-Icelandic]. University of Bergen MA thesis.

Seefranz-Montag, Ariane von. 1982. Syntaktische Funktionen und Wortstellungs veränderung: Die Entwicklung 'subjektloser' Konstruktionen in einigen Sprachen. Munich: Fink.

Serzant, Ilja A. 2015. An Approach to Syntactic Reconstruction. Perspectives on Historical Syntax, ed. by Carlotta Viti, 117-154. Amsterdam: John Benjamins.

Smitherman, Thomas. 2015. Reconstructing Non-Canonical Argument Structure for Proto-Indo-European: Methodological Questions and Progress. Perspectives on Historical Syntax, ed. by Carlotta Viti, 95-116. Amsterdam: John Benjamins. 
Tomasello, Michael. 2003. Constructing a Language: Usage-Based Theory of Language Acquisition. Cambridge, Ma.: Harvard University Press.

Viti, Carlotta. 2014. Reconstructing Syntactic Variation in Proto-Indo-European. Indo-European Linguistics 2: 73-111.

Vazquez Gonzalez, Juan G. \& Jóhanna Barðdal. 2019. Reconstruction the Ditransitive Construction for Proto-Germanic: Gothic, Old English and Old Norse-Icelandic. Folia Linguistica Historica 40(2): 555-620.

Vries, Jan de. 1962. Altnordisches Etymologisches Wörterbuch. 2nd Ed. Leiden: Brill.

Walkden, George. 20o9. The Comparative Method in Syntactic Reconstruction. Cambridge University M.Phil. thesis.

Walkden, George. 2013. The Correspondence Problem in Syntactic Reconstruction. Diachronica 30(1): 95-122.

Walkden, George. 2014. Syntactic Reconstruction and Proto-Germanic. Oxford: Oxford University Press.

Watkins, Calvert. 1964. Preliminaries to the Reconstruction of Indo-European Sentence Structure. Proceedings of the IX International Congress of Linguists, ed. by H. G. Lunt, 1035-1045. The Hague: Mouton.

Watkins, Calvert. 1976. Towards Proto-Indo-European Syntax: Problems and Pseudoproblems. Papers from the Parasession on Diachronic Syntax, ed. by Sanford B. Steever, Carol A. Walker \& Salokoko S. Mufwene, 306-326. Chicago: Chicago Linguistic Society.

Watkins, Calvert. 1995. How to Kill a Dragon: Aspects of Indo-European Poetics. Oxford: Oxford University Press.

Wegener, Heide. 1985. Der Dativ im heutigen Deutsch. Tübingen: Narr.

Willis, David. 2011. Reconstructing Last Week's Weather: Syntactic Reconstruction and Brythonic Free Relatives. Journal of Linguistics 47(2): 407-446.

Winter, Werner. 1984. Reconstructional Comparative Linguistics and the Reconstruction of the Syntax of Undocumented Stages in the Development of Languages and Language Families. Historical Syntax, ed. by Jacek Fisiak, 613-625. The Hague: Mouton. 